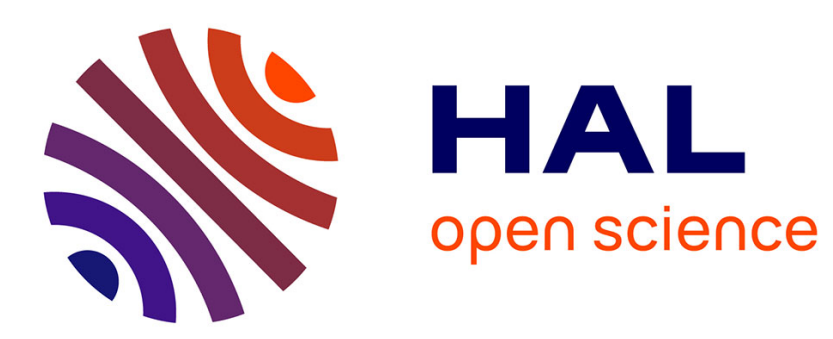

\title{
Induction of unreduced megaspores with high temperature during megasporogenesis in Populus
}

Wang, Li, Kang

\section{To cite this version:}

Wang, Li, Kang. Induction of unreduced megaspores with high temperature during megasporogenesis in Populus. Annals of Forest Science, 2012, 69 (1), pp.59-67. 10.1007/s13595-011-0152-5 . hal00930723

\section{HAL Id: hal-00930723 \\ https://hal.science/hal-00930723}

Submitted on 1 Jan 2012

HAL is a multi-disciplinary open access archive for the deposit and dissemination of scientific research documents, whether they are published or not. The documents may come from teaching and research institutions in France or abroad, or from public or private research centers.
L'archive ouverte pluridisciplinaire $\mathbf{H A L}$, est destinée au dépôt et à la diffusion de documents scientifiques de niveau recherche, publiés ou non, émanant des établissements d'enseignement et de recherche français ou étrangers, des laboratoires publics ou privés. 


\title{
Induction of unreduced megaspores with high temperature during megasporogenesis in Populus
}

\author{
Jun Wang $\cdot$ Dai-Li Li $\cdot$ Xiang-Yang Kang
}

Received: 18 May 2011 / Accepted: 19 October 2011 /Published online: 15 November 2011

(C) INRA / Springer-Verlag France 2011

\begin{abstract}
- Introduction Triploid breeding is one of the most powerful approaches for improvement of the genus Populus L. Pollination with artificial unreduced $(2 n)$ pollen was inefficiency, owing to weak competition of $2 n$ pollen. To induce $2 n$ megaspores and improve the efficiency of triploid production, female buds of Populus pseudo-simonii $\times$ Populus nigra 'Zheyin3\#' were exposed to high temperature during megasporogenesis.

- Results A relationship between megasporogenesis and morphological changes of female buds was established to guide the high-temperature treatments. In the progeny, 146 triploids were obtained and the highest efficiency of triploid production was $66.7 \%$. Both $41^{\circ} \mathrm{C}$ and $44^{\circ} \mathrm{C}$ were suitable for megaspore chromosome doubling. Cytological analysis showed that meiotic stages from pachytene to diplotene may be the optimal period for megaspore chromosome doubling at high temperature in the 'Zheyin3\#.' Because
\end{abstract}

Handling Editor: Luc Paques

J. Wang $\cdot$ X.-Y. Kang

National Engineering Laboratory for Tree Breeding,

Beijing Forestry University,

100083, Beijing, People's Republic of China

J. Wang $\cdot$ D.-L. Li $\cdot$ X.-Y. Kang

Key Laboratory of Genetics and Breeding in Forest Trees and Ornamental Plants, MOE, Beijing Forestry University, 100083, Beijing, People's Republic of China

J. Wang $(\bowtie) \cdot$ X.-Y. Kang $(\bowtie)$

Beijing Forestry University,

P. O. Box 118, NO.35, Tsinghua East Rd. Haidian District,

100083, Beijing, People's Republic of China

e-mail: wangjun@bjfu.edu.cn

e-mail: kangxy@bjfu.edu.cn megasporocytes both in the first meiotic division and the second division were treated, the first meiotic division restitution typed and the second meiotic division restitution typed $2 n$ megaspores could be obtained.

- Conclusion Our findings indicated that hybridization with high-temperature-induced $2 n$ megaspores is an ideal approach for triploid production. Offspring with different heterozygosity are valuable for genetic research and breeding programs of Populus.

Keywords Populus . Triploid . Unreduced megaspore . High temperature $\cdot$ FDR $\cdot$ SDR

\section{Introduction}

Triploid breeding is one of the most powerful approaches for improvement of the genus Populus L. The first discovered triploid $(2 n=3 x=57)$ individual of Populus was a giant form of Populus tremula L. from a natural population in Sweden, which was characterized by extremely large leaves and fast growth (Nilsson-Ehle 1936; Müntzing 1936). Subsequently, triploids were selected or created by breeding in a number of Populus species and exhibited good performance in growth and pulpwood properties (van Buijtenen et al. 1958; Weisgerber et al. 1980; Zhu et al. 1995). In China, some triploid hybrids of Populus tomentosa Carr. have been widely deployed in the northern provinces including Beijing, Shandong, Hebei, Henan, and Shanxi. Many important cultivars, such as $P . \times$ canadensis Moench cv. 'I-214,' $P . \times$ euramericana (Dode) Guiner CL. 'Zhonglin-46,' $P . \times$ canadensis Moench cv. 'Sacrau 79,' $P . \times$ euramericana (Dode) Guiner cv. 'Wuhei-1,' $P . \times$ liaohenica, and $P . \times$ langfangensis-3 Wang, have been detected as triploids 
(Zhang et al. 2004, 2005). These Populus triploids supply a significant amount of materials for the wood industry in China.

Populus triploids can be produced by crossing diploids with triploids or tetraploids (Winton and Einspahr 1970; Harder et al. 1976; Einspahr 1984) or utilization of spontaneous or artificial unreduced $(2 n)$ pollen (Johnsson and Eklundh 1940; Seitz 1954; Mashkina et al. 1989; Zhu et al. 1995; Kang et al. 2000b). However, triploids generate triploid seeds difficultly due to irregular meiosis (Müntzing 1936; Johnsson 1940; Kang et al. 1999; Wang et al. 2010a). Other limitations for triploid production include a lack of tetraploid parents and weak competition of $2 n$ pollen (Kang and Zhu 1997). Recently, hybridization with induced $2 n$ eggs was proven as an efficient method for triploid production ( $\mathrm{Li}$ et al. 2008; Wang et al. 2010b).

$\mathrm{Li}$ et al. (2008) successfully induced $2 n$ megaspores by treating Populus alba L. $\times$ Populus glandulosa Torr. female buds in the first meiotic division of megasporocytes with colchicine solution. They produced 12 triploid hybrids by crossing the treated female buds with normal diploid male parent, with $16.7 \%$ triploid production in the best treatment. Wang et al. (2010b) reported a novel approach for $2 n$ egg induction by colchicine treatment of Populus pseudo-simonii Kitag. $\times$ Populus nigra L. 'Zheyin3\#' female catkins during embryo sac development, defined as "embryo sac chromosome doubling," resulting in $66.7 \%$ triploid production. Although embryo sac chromosome doubling was more efficient for $2 n$ egg production, $2 n$ eggs derived from megaspore chromosome doubling should be more valuable for improvement programs of Populus because it can provide more heterozygous progeny. Thus, improvement of techniques for megaspore chromosome doubling is necessary to increase the efficiency of triploid production.

Colchicine treatment was found to be effective for $2 n$ egg induction in Populus ( $\mathrm{Li}$ et al. 2008; Wang et al. 2010b), but procedures are complicated and time-consuming. High temperature has been shown to be effect in inducing polyploid in plants (Randolph 1932; Mashkina et al. 1989; Kang et al. 2000a; Zhang et al. 2002) and animals (Nomura et al. 2004; Yang and Guo 2006). More importantly, it has some economic and procedural advantages. In this study, high-temperature treatment of Populus 'Zheyin3\#' female buds during megasporogenesis was used to investigate the possibility of $2 n$ egg induction and to improve the efficiency of triploid production.

\section{Materials and methods}

\subsection{Plant materials}

Floral branches of a female parent $P$. pseudo-simonii $\times$ P. nigra 'Zheyin3\#' $(2 n=2 x=38)$ were collected from a plantation in Tongliao City (Inner Mongolia Autonomous Region, People's Republic of China). Floral branches of a male parent $P . \times$ beijingensis $\mathrm{W}$. Y. Hsu $(2 n=2 x=38)$ were collected at the campus of Beijing Forestry University. The branches were cultured in water to force floral development in a greenhouse $\left(10-20^{\circ} \mathrm{C}\right)$.

\subsection{Cytological observation of megasporogenesis}

According to Wang et al. (2010b), the megasporogenesis of the 'Zheyin3\#' is almost complete before pollination. Thus, after the branches were cultured in the greenhouse, three 'Zheyin3\#' female flower buds were collected from the branches every $12 \mathrm{~h}$ until pollination. After morphological characteristics of the buds were photographically recorded by a stereomicroscope (Olympus SZX12) with an Olympus C5060 Wide Zoom camera, they were fixed in FAA (70\% ethanol/acetic acid $/ 40 \%$ formaldehyde, 90:5:5) immediately at $4{ }^{\circ} \mathrm{C}$ for $24 \mathrm{~h}$. Subsequently, ovaries from each fixed bud were embedded with paraffin and sectioned at $8-10 \mu \mathrm{m}$. The sections were stained with iron hematoxylin and observed under an Olympus BX51 microscope. The relationship between floral morphological characteristics and female meiotic stage is presented in Table 1. Subsequently, the ontogeny of the 'Zheyin3\#' female buds was subdivided into seven stages corresponding with floral morphological changes and used to guide heat treatments.

Table 1 Relationship between floral morphological characteristics and female meiotic stage of $P$. pseudo-simonii $\times$ P. nigra 'Zheyin3\#'

\begin{tabular}{llll}
\hline Days of culture & Female floral stage & Floral morphological characteristics & Representative female meiotic stages \\
\hline 9.5 & I & Bud is tightly wrapped by bract scales & MMC-early leptotene \\
10.5 & II & Slight bulginess in the mid bud region & MMC-late leptotene \\
13 & III & Bract scales dehisced slightly, catkin not emerged & Leptotene-diakinesis \\
13.5 & IV & Bract scales dehisced and catkin slightly emerged & Pachytene-prophase II \\
15 & V & One third of the catkin outside of bract scales & Diakinesis-telophase II \\
15.5 & VI & Half of the catkin outside of bract scales & Prophase II-tetrad \\
16.5 & VII & Two third of the catkin outside of bract scales & Metaphase II-uninucleate embryo sac \\
\hline
\end{tabular}

$M M C$ megaspore mother cell 


\subsection{Treatment with high temperature}

Female buds at stages II, III, IV, V, and VI in megasporogenesis were selected to conduct treatments. These buds were exposed to $38^{\circ} \mathrm{C}, 41^{\circ} \mathrm{C}$, and $44^{\circ} \mathrm{C}$ for 3 and $5 \mathrm{~h}$, respectively. Untreated buds were defined as the control group. In order to determine the effective meiotic stages for megaspore chromosome doubling, three untreated buds at each morphological stage (stages II-VI) (15 buds total) were fixed with FAA. Ten ovaries randomly selected from each fixed bud (150 ovaries total) were used for statistical analysis.

When stigmas of the treated buds were receptive, they were pollinated with fresh pollen of $P$. $\times$ beijingensis. Seeds matured after approximately 30 days cultivation. They were collected and germinated in sterile soil. When the seedlings grew to approximately $5 \mathrm{~cm}$ in height, they were transferred into containers with nutritious soil to promote growth. Subsequently, surviving seedlings were transplanted in the field at approximately $30 \mathrm{~cm}$ height.

\subsection{Detection of ploidy level in progeny}

Both flow cytometry and somatic chromosome counting were used to detect the ploidy level of offspring. Flow cytometric analysis was conducted according to Galbraith et al. (1983). Briefly, young leaves of the seedlings were chopped in a modified Galbraith's buffer $\left(45 \mathrm{mM} \mathrm{MgCl} 2 \cdot 6 \mathrm{H}_{2} \mathrm{O}, 20 \mathrm{mM}\right.$ MOPS, $30 \mathrm{mM}$ sodium citrate, $0.5 \%$ Triton X-100, $1 \%$ PVP10 , pH 7.0) using a sharp razor blade on ice. Subsequently, the nuclear suspension was filtered through a $40-\mu \mathrm{m}$ nylon mesh to remove large debris. Nuclei were stained with $50 \mu \mathrm{g} \mathrm{mL}^{-1}$ propidium iodide with RNase at $50 \mu \mathrm{g} \mathrm{mL} \mathrm{m}^{-1}$. After incubation on ice for $30 \mathrm{~min}$ in the dark, samples were analyzed with a BD FACSCalibur flow cytometer. A known diploid plant from the progeny was used as a control.
After flow cytometric analysis, ploidy levels of all putative triploid plants were confirmed by somatic chromosome counting. Stem tips were removed from the seedlings and pretreated with a saturated solution of paradichlorobenzene for $4 \mathrm{~h}$ at $25^{\circ} \mathrm{C}$. Subsequently, the materials were fixed in a fresh Farmer's solution (ethanol/acetic acid, 3:1) for $24 \mathrm{~h}$ at $4^{\circ} \mathrm{C}$, and then hydrolyzed in $38 \% \mathrm{HCl} /$ ethanol (1:1) for $25 \mathrm{~min}$ at room temperature. After washing in distilled water three times for $15 \mathrm{~min}$, the hydrolyzed materials were squashed in a carbol fuchsin solution. Chromosome counts of at least 20 cells with a well-spread metaphase per seedling were observed using an Olympus BX51 microscope.

\subsection{Statistical analysis}

The data of triploid production efficiency were analyzed using ANOVA to assess for differences among floral stages and temperatures and between durations. When treatments were significantly different, a least significant difference (LSD) multiple comparison test was used for pairwise comparison. Prior to analysis, data of the percent triploid production rate were transformed by the arcsin of the square root of $\mathrm{p} / 100$. Pearson's correlation coefficient was calculated between the rate of triploid production and the percentage of certain female meiotic stage. All statistical analyses were performed using the SPSS software (version 18.0).

\section{Results}

3.1 Flower bud morphogenesis and relationship with female meiotic stage

In the greenhouse, megasporogenesis of the 'Zheyin3\#' was initiated 9.5 days after being cultured. More than one meiotic stage was observed in each female bud due to asynchronous
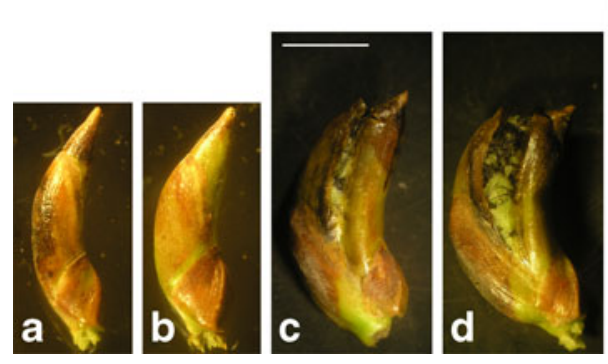

Fig. 1 Female bud development of Populus pseudo-simonii $\times$ P. nigra 'Zheyin3\#' (Bar=5 mm). a Stage I bud, which is tightly wrapped by bract scales; b stage II bud with slight bulge in the middle; c stage III bud with slightly dehisced bract scales; d stage IV bud with a slightly emerged catkin; e stage V bud, characterized by approximately one

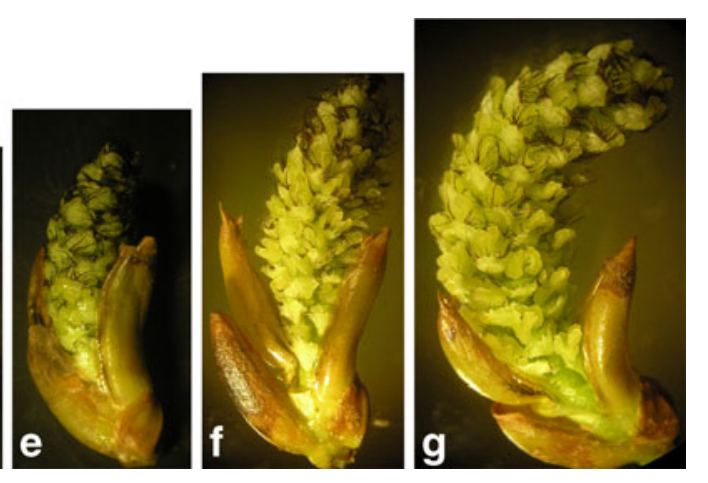

third of the catkin outside of bract scales; f stage VI bud with approximately half of the catkin outside of bract scales; $g$ stage VII bud with approximately two third of the catkin emerged outside the bract scales 
development of megasporocytes in different ovaries. Megasporogenesis of all megasporocytes finished between 15.5 and 17.5 days after being cultured due to the asynchrony.

The relationship between flower bud morphological characteristics and female meiotic stage was established to guide high-temperature treatments (Table 1). The ontogeny of the 'Zheyin3\#' female buds was subdivided into seven stages based on a series of morphological changes. Buds at stage I, which were tightly wrapped by bract scales (Fig. 1a), began to undergo female meiosis and some megasporocytes had been in early leptotene (Fig. 2a). Stage II buds were characterized by the slight bulge in mid region of buds, corresponding with late leptotene of megasporocytes marked by bouquet-shaped nuclear chromosomes (Fig. 2b). Stage III was defined when bud bract scales had slightly dehisced but the catkins had not emerged (Fig. 1c). Most megasporocytes in this stage of buds were in leptotene to diakinesis (Fig. 2ae). Stage IV occurred when the bract scales dehisced and the catkins started to emerge (Fig. 1d), with megasporocytes having the meiotic stages from pachytene to prophase II (Fig. 2c-h). In buds at stage V, approximately one third of the catkins had emerged from the bract scales (Fig. 1e), corresponding to most megasporocytes at diakinesis to telophase II (Fig. 2e-k). Approximately half of the catkins
Fig. 2 Megasporogenesis of $P$. pseudo-simonii $\times$ P. nigra 'Zheyin3\#' (Bar=10 $\mu \mathrm{m})$. a Early leptotene; b Late leptotene; c Pachytene; d Diplotene; e Diakinesis; f Metaphase I; $\mathbf{g}$ Telophase I; $\mathbf{h}$ Prophase II; i Metaphase II; $\mathbf{j}$ and $\mathbf{k}$ Anaphase II (serial sections); I Tetrad
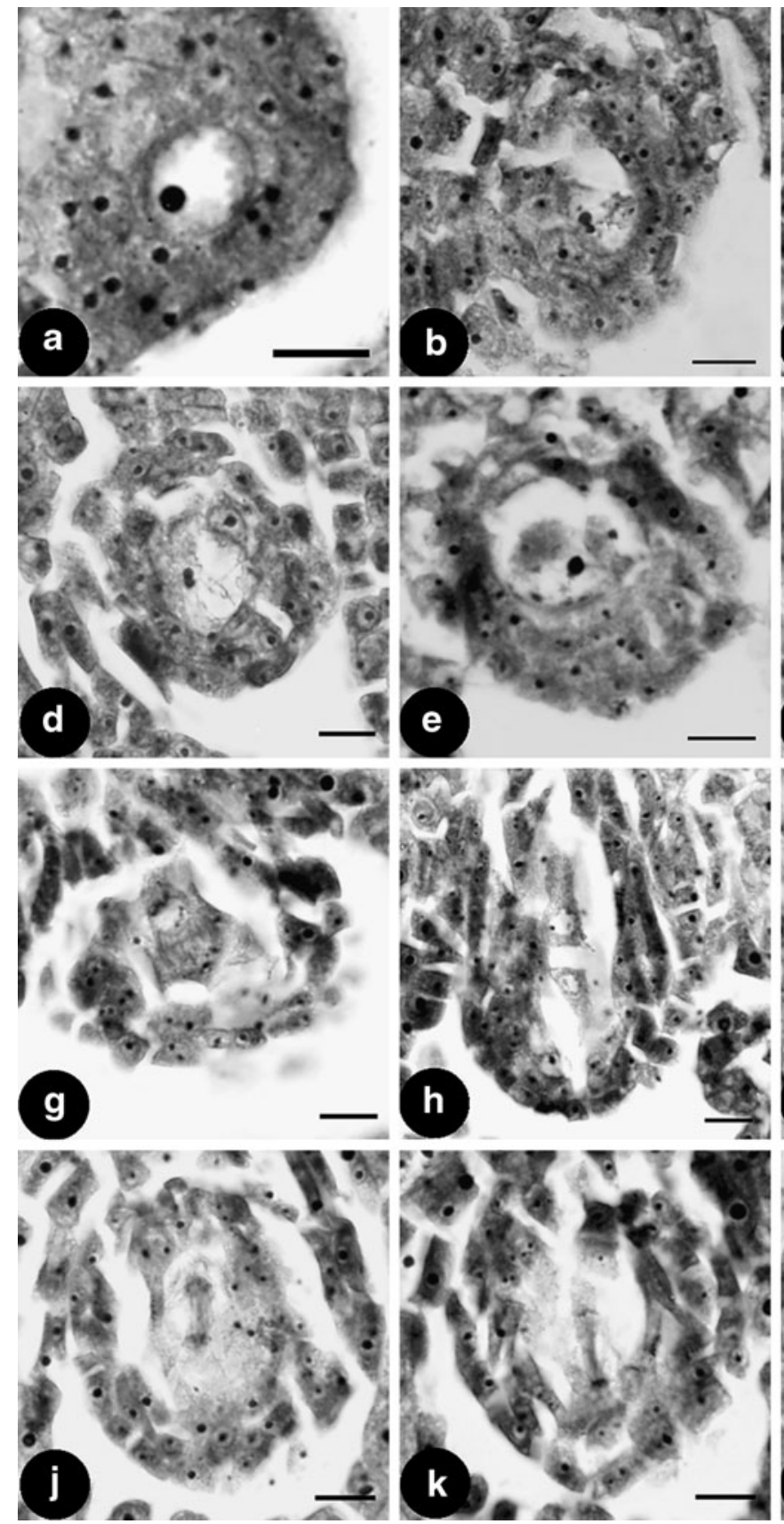

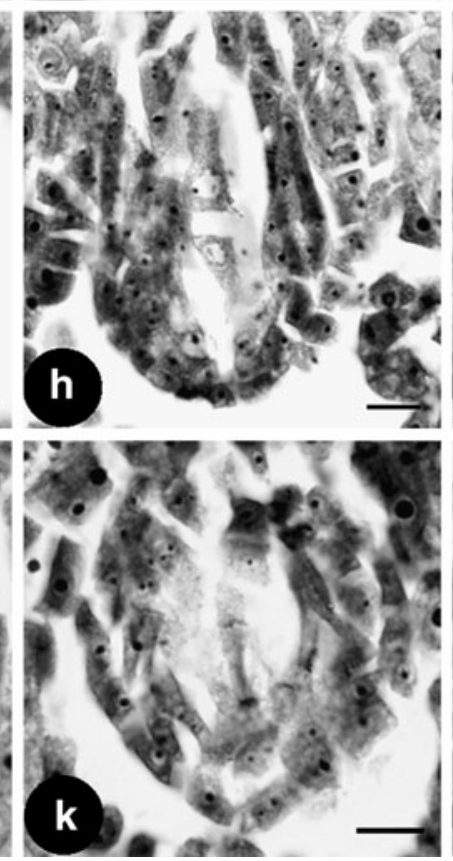

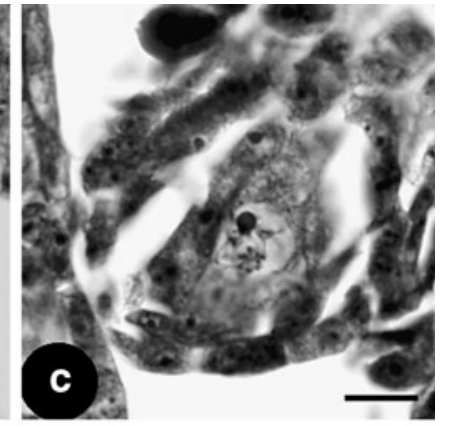
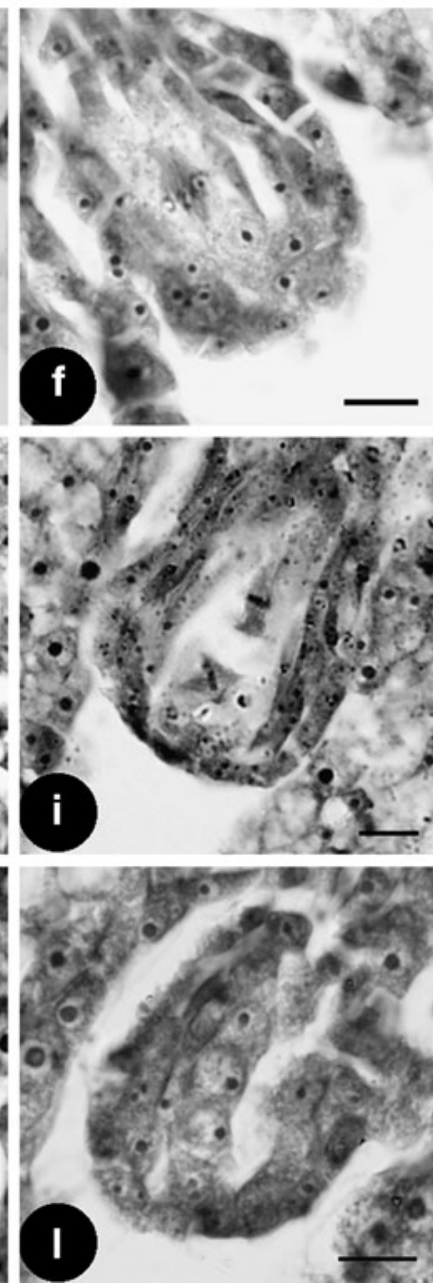
Fig. 3 Ploidy level detection of offspring derived from megaspore chromosome doubling with high temperature in $P$. pseudo-simonii $\times P$. nigra 'Zheyin3\#'. a Somatic chromosome number of triploid $(2 n=3 x=57)($ Bar $=10 \mu \mathrm{m}) ; \mathbf{b}$ Flow cytometric detection of nuclei mixture of young leaves from diploid and triploid plants
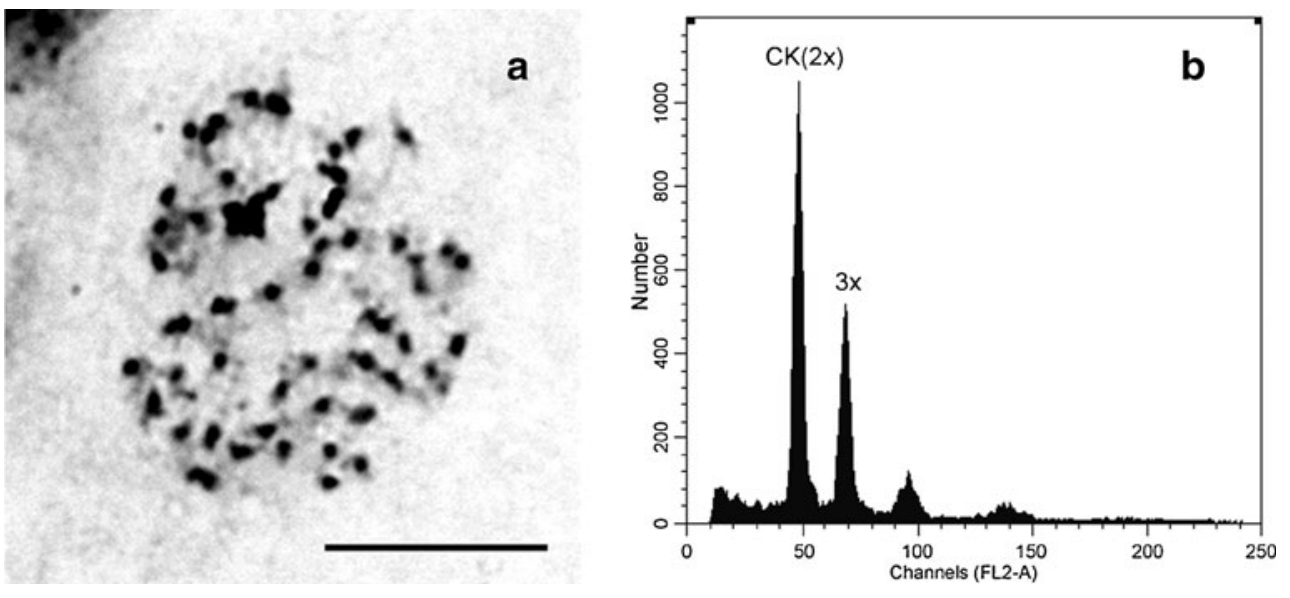

Table 2 Triploid production by high-temperature-induced megaspore chromosome doubling in $P$. pseudo-simonii $\times P$. nigra 'Zheyin3\#'

\begin{tabular}{|c|c|c|c|c|c|c|}
\hline $\begin{array}{l}\text { Female } \\
\text { floral stage }\end{array}$ & $\begin{array}{l}\text { Treatment } \\
\text { temperature }\left({ }^{\circ} \mathrm{C}\right)\end{array}$ & $\begin{array}{l}\text { Treatment } \\
\text { duration }(\mathrm{h})\end{array}$ & $\begin{array}{l}\text { Seed } \\
\text { number }\end{array}$ & $\begin{array}{l}\text { Seedling } \\
\text { number }\end{array}$ & $\begin{array}{l}\text { Triploid } \\
\text { number }\end{array}$ & $\begin{array}{l}\text { Triploid } \\
\text { production rate }(\%)\end{array}$ \\
\hline \multirow[t]{6}{*}{ Stage II } & \multirow[t]{2}{*}{38} & 3 & 69 & 17 & 0 & 0 \\
\hline & & 5 & 36 & 11 & 0 & 0 \\
\hline & \multirow[t]{2}{*}{41} & 3 & 6 & 2 & 0 & 0 \\
\hline & & 5 & 28 & 13 & 1 & 7.69 \\
\hline & \multirow[t]{2}{*}{44} & 3 & - & - & - & - \\
\hline & & 5 & - & - & - & - \\
\hline \multirow[t]{6}{*}{ Stage III } & \multirow[t]{2}{*}{38} & 3 & 122 & 0 & - & - \\
\hline & & 5 & 107 & 26 & 0 & 0 \\
\hline & \multirow[t]{2}{*}{41} & 3 & 42 & 3 & 2 & 66.67 \\
\hline & & 5 & 112 & 19 & 7 & 36.84 \\
\hline & \multirow[t]{2}{*}{44} & 3 & - & - & - & - \\
\hline & & 5 & - & - & - & - \\
\hline \multirow[t]{6}{*}{ Stage IV } & \multirow[t]{2}{*}{38} & 3 & 108 & 27 & 0 & 0 \\
\hline & & 5 & 232 & 87 & 10 & 11.49 \\
\hline & \multirow[t]{2}{*}{41} & 3 & 173 & 110 & 24 & 21.82 \\
\hline & & 5 & 198 & 124 & 26 & 20.97 \\
\hline & \multirow[t]{2}{*}{44} & 3 & 87 & 55 & 20 & 36.36 \\
\hline & & 5 & 81 & 25 & 15 & 60.00 \\
\hline \multirow[t]{6}{*}{ Stage V } & \multirow[t]{2}{*}{38} & 3 & 149 & 13 & 0 & 0 \\
\hline & & 5 & 150 & 22 & 3 & 13.64 \\
\hline & \multirow[t]{2}{*}{41} & 3 & 188 & 60 & 2 & 3.33 \\
\hline & & 5 & 97 & 14 & 2 & 14.29 \\
\hline & \multirow[t]{2}{*}{44} & 3 & 161 & 10 & 3 & 30.00 \\
\hline & & 5 & 209 & 22 & 8 & 36.36 \\
\hline \multirow[t]{6}{*}{ Stage VI } & \multirow[t]{2}{*}{38} & 3 & 251 & 109 & 1 & 0.92 \\
\hline & & 5 & 175 & 57 & 3 & 5.26 \\
\hline & \multirow[t]{2}{*}{41} & 3 & 111 & 47 & 3 & 6.38 \\
\hline & & 5 & 91 & 46 & 5 & 10.87 \\
\hline & \multirow[t]{2}{*}{44} & 3 & 143 & 51 & 5 & 9.80 \\
\hline & & 5 & 127 & 39 & 6 & 15.38 \\
\hline Control & & & 479 & 127 & 0 & 0 \\
\hline Total & & & 3,732 & 1,136 & 146 & \\
\hline
\end{tabular}


in stage VI buds had emerged outside the bract scales 15.5 days after being cultured (Fig. 1f), and most megasporocytes were in prophase II to tetrad (Fig. 2h-1). When approximately two thirds of the catkins emerged outside the bract scales of buds (stage VII, Fig. 1g), a number of cells had developed into uninucleate embryo sacs.

\subsection{Triploid production}

After female buds of the 'Zheyin3\#' were treated with high temperature, bud development was retarded, and the stigmas became dry and brown. Some buds treated with high temperature died, resulting in no seed collection for some treatments.

A total of 3,732 seeds were collected from surviving treated and control buds. After seed sowing and transferring of young seedlings, 1,136 seedlings remained in field. All offspring were examined by flow cytometry, and 146 putative triploids were screened. Further somatic chromosome counting showed that all these putative triploids were real triploids $(2 n=3 x=57$, Fig. 3a), which indicated that flow cytometric analysis was a reliable method for ploidy level determination of Populus. All triploids were from the treated groups. No triploids were found in the control group, suggesting that $2 n$ egg formation and fertilization between normal eggs and $2 n$ pollen rarely occur.

The number and efficiency of triploid production in treatments of different stage of buds are presented in Table 2. According to the data of triploid production efficiency, ANOVA analysis revealed significant difference among the female bud stages $(F=3.039, p=0.046)$ and highly significant difference among the treatment temperatures $(F=11.073, p=$
0.001). The difference of treatment durations was not significant $(F=1.608, p=0.222)$. Further LSD multiple comparison tests showed that although the difference of triploid production efficiency among stages III, IV, and V buds were not significant, they were all significantly better than stage II buds at $\alpha=0.05$ level. And the treatments with $41^{\circ} \mathrm{C}$ and $44^{\circ} \mathrm{C}$ were significantly better than $38^{\circ} \mathrm{C}$, suggesting that both the temperature of $41^{\circ} \mathrm{C}$ and $44^{\circ} \mathrm{C}$ were suitable for megaspore chromosome doubling.

\subsection{The effective meiotic stages}

for high-temperature-induced megaspore

chromosome doubling

To determine the effective meiotic stages for megaspore chromosome doubling, a total of 1,277 ovules from 15 fixed female buds at different treated stages were analyzed by paraffin sectioning. Table 3 presents a percentage change of different meiotic stages in each flower bud stage for megaspore chromosome doubling. Although each bud stage had asynchronous meiotic development, some meiotic stages were predominant. For example, in stage IV buds, the frequencies of megasporocytes at diplotene and diakinesis stages were $26.52 \%$ and $36.28 \%$, respectively, which was higher than other meiotic stages in the same buds.

Pearson's correlation analyses between the percentage of certain meiotic stage and the rate of triploid production in treatments with $41^{\circ} \mathrm{C}$ for $5 \mathrm{~h}$, which was one of the best conditions for megaspore chromosome doubling, in different female bud stages revealed that the percentage of both pachytene and diplotene were significant positively correlated
Table 3 Detailed presentation of megasporocyte development at different female floral stages for treatments

$M M C$ megaspore mother cell

\begin{tabular}{|c|c|c|c|c|c|}
\hline \multirow[t]{2}{*}{ Developmental stage of megasporocytes } & \multicolumn{5}{|c|}{ Frequency of each developmental stage of megasporocytes (\%) } \\
\hline & Stage II & Stage III & Stage IV & Stage V & Stage VI \\
\hline Archesporial cell & 21.09 & & & & \\
\hline MMC & 43.54 & 0.64 & & & \\
\hline Early leptotene & 18.37 & 11.18 & 1.22 & & \\
\hline Late leptotene & 12.93 & 15.02 & 6.40 & 2.53 & \\
\hline Pachytene & 4.08 & 19.49 & 10.06 & 1.08 & \\
\hline Diplotene & & 28.12 & 26.52 & 3.97 & \\
\hline Diakinesis & & 18.21 & 36.28 & 5.05 & 0.94 \\
\hline Metaphase I & & 4.79 & 8.54 & 7.58 & 5.19 \\
\hline Anaphase I and telophase I & & 0.96 & 2.13 & 6.14 & 7.55 \\
\hline Prophase II & & 1.60 & 5.79 & 28.52 & 12.74 \\
\hline Metaphase II & & & 1.52 & 20.22 & 20.75 \\
\hline Anaphase II & & & 1.52 & 10.11 & 27.83 \\
\hline Telophase II and tetrad & & & & 12.64 & 17.92 \\
\hline $\begin{array}{l}\text { Functional megaspore } \\
\text { and uninucleate embryo sac }\end{array}$ & & & & 2.17 & 7.08 \\
\hline
\end{tabular}



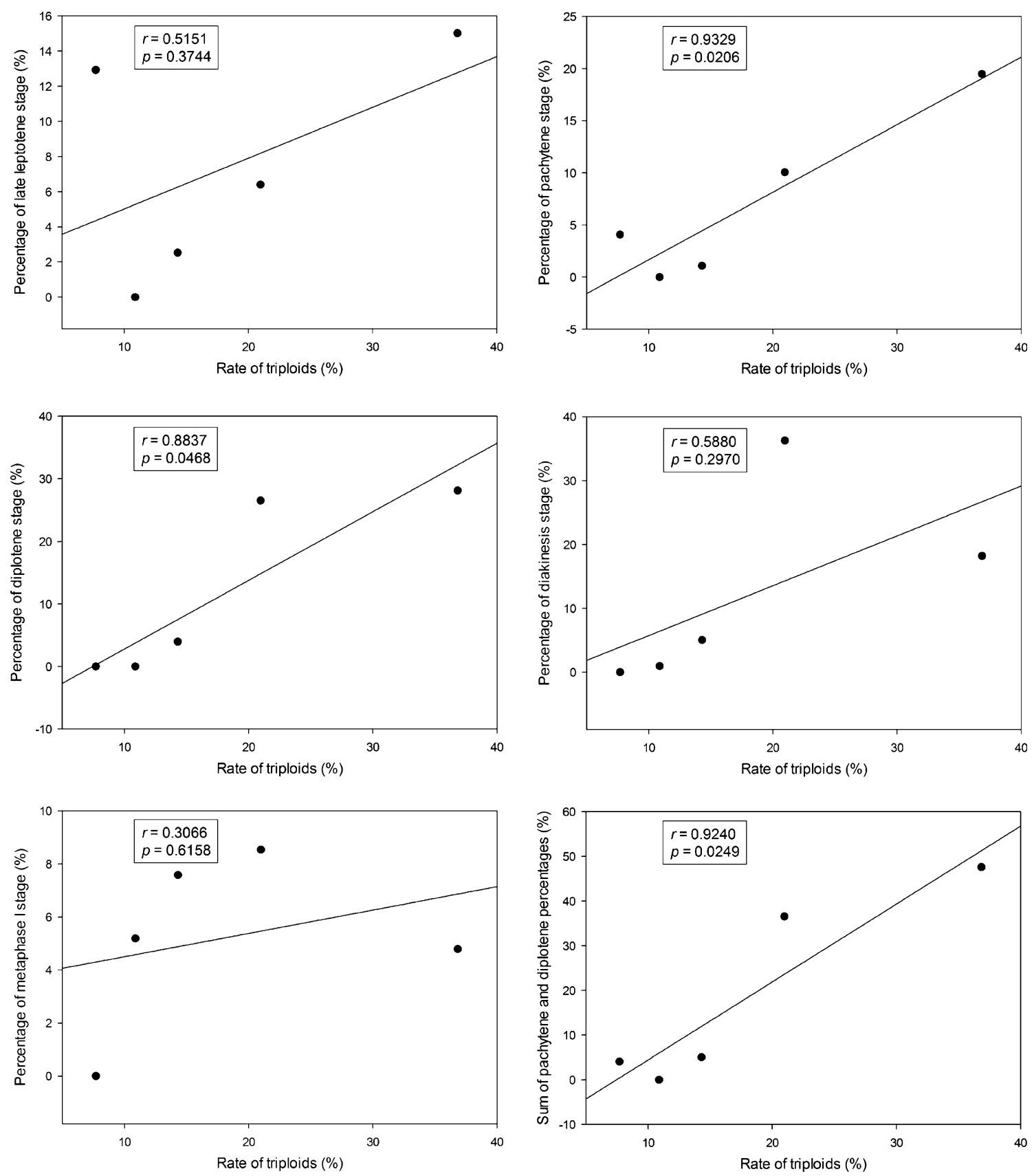

Fig. 4 Pearson's correlation analyses between rate of triploids and percentage of female meiotic stages

with the triploid production efficiency $(r=0.9329, p=0.0206$ and $r=0.8837, p=0.0468$, respectively, Fig. 4). However, it was notable that either the percentage values of pachytene or diplotene cannot match the triploid efficiency. Furthermore, the sum of percentages of pachytene and diplotene stages was also significantly correlated with the efficiency of triploid production $(r=0.9240, p=0.0249)$, suggesting that the period from pachytene and diplotene stages may be the optimal period for megaspore chromosome doubling at high temperature in the 'Zheyin3\#.' The first meiotic inhibition is similar to mechanism of the first meiotic division restitution (FDR) of $2 n$ gamete formation, generating FDR typed $2 n$ megaspores.

Additionally, we found that the percentages of both pachytene and diplotene were considerably low $(5.05 \%)$ in the stage V bud, even null in stage VI bud, which did not correspond to the triploid production efficiency, suggesting that some other meiotic stages may be effective for $2 n$ megaspore induction. In stages V and VI buds, a high proportion of megasporocytes were at the second meiotic division (Table 3), 
inferring that meiotic inhibition at the second meiotic division can also form $2 n$ megaspores, which is equal to the mechanism of the second meiotic division restitution (SDR) of $2 n$ gamete formation.

\section{Discussion}

In previous studies, high temperature was usually used to induce $2 n$ pollen in plants (Randolph 1932; Mashkina et al. 1989; Kang et al. 2000a; Zhang et al. 2002). Mashkina et al. (1989) and Kang and Zhu (1997) induced more than $80 \% 2 n$ pollen with high temperature in Populus. However, the efficiency of triploid production through pollination with induced $2 n$ pollen was low $(12.9 \%$ at most, published in Kang et al. 2000b), owing to competition from normal pollen (Kang and Zhu 1997). In this study, we used hightemperature exposure to induce megaspore chromosome doubling and successfully produced 146 triploid plants of Populus, suggesting high temperature is an efficient agent for $2 n$ egg induction. The highest efficiency of triploid production in the present study was $66.7 \%$, which was much more than the efficiency of pollination with $2 n$ pollen, showing that hybridization with induced $2 n$ megaspores is a more ideal approach for triploid production in Populus.

Colchicine is considered as the most important mitogen for polyploid induction. In polyploid breeding program of Populus, Li et al. (2008) obtained 12 triploids (16.7\% highest production rate) through megaspore chromosome doubling with colchicine solution. In the present study, hightemperature treatments exhibited a better result in megaspore chromosome doubling (146 triploids and 66.7\% production efficiency), demonstrating that high temperature is more suitable for $2 n$ megaspore induction of Populus than colchicine. However, since the response of female gametophytes to high temperature can vary according to genotype (Wahid et al. 2007), the temperature range and duration should be adjusted with different genotypes of Populus.

It is important for gamete chromosome doubling to apply the mutagenic agent to cells at a suitable developmental stage. The pachytene stage of meiosis was found to be optimal for colchicine-induced $2 n$ megaspore induction of Populus (Li et al. 2008). In the present study, the most suitable stage for $2 n$ megaspore induction with high temperature was from pachytene to diplotene. This was slightly later than the optimal stages induced with colchicine, possibly because the diffusion of colchicine solution inside the ovule was slower than the conduction of heat.

In general, tolerance to heat stress varies among different plant organs; ovules are less sensitive to high-temperature stress than pollen (Wahid et al. 2007). In previous studies, $38^{\circ} \mathrm{C}$ was most suitable for high-temperature $2 n$ pollen induction in Populus (Mashkina et al. 1989; Kang et al. 2000a). Excessively high temperature inhibited pollen formation. In this study, although $38^{\circ} \mathrm{C}$ treatments produced many seeds, triploid production was relatively low. The most suitable temperatures for $2 n$ megaspore production were $41^{\circ} \mathrm{C}$ to $44^{\circ} \mathrm{C}$, which was higher than that for $2 n$ pollen induction. This suggests that megasporocytes have higher tolerance to high temperature than microsporocytes in Populus.

Diploid gametes play important roles in plant evolution. The mechanism of $2 n$ gamete formation was reviewed by Veilleux (1985) and Bretagnolle and Thompson (1995). The genetic consequences in polyploid progeny vary, depending on the mechanism for $2 n$ gamete formation. Theoretically, FDR typed $2 n$ gametes can transmit approximately $80 \%$ parental heterozygosity to the progeny and SDR typed $2 n$ gametes transmit approximately 40\% (Mendiburu and Peloquin 1977). In the study of Li et al. (2008), all treatments were conducted to megasporocytes during the first meiotic division, resulting in $2 n$ egg formation was similar to the FDR type. The $2 n$ eggs induced in the study of Wang et al. (2010b) should be completely homozygous, owing to their origin in mitotic inhibition. In our study, not only FDR $2 n$ megaspores but also SDR $2 n$ megaspores were produced, which generated offspring with different heterozygosity. These triploid hybrids with different heterozygosity are valuable for genetic research and breeding programs of Populus. Future studies will be necessary to verify the heterozygosity of offspring through molecular analysis.

Acknowledgments We thank the Forestry Research Institute of Tongliao City, the Inner Mongolia Autonomous Region, People's Republic of China, for collecting the plant material and for additional help. This work was supported by the Fundamental Research Funds for the Central Universities (grant no. YX2010-17) and the National Natural Science Foundation of China (grant nos. 30671708 and 31000306).

\section{References}

Bretagnolle F, Thompson JD (1995) Gametes with the somatic chromosome number: mechanisms of their formation and role in the evolution of polyploid plants. New Phytol 129:1-22

Einspahr DW (1984) Production and utilization of triploid hybrid aspen. Iowa State J Res 58:401-409

Galbraith DW, Harkins KR, Maddox JM, Ayres NM, Sharma DP, Firoozabady E (1983) Rapid flow cytometric analysis of the cell cycle in intact plant tissues. Science 220:1049-1051

Harder ML, Verhagen S, Winton L, Einspahr DW (1976) Tetraploid aspen production using unreduced pollen from triploid males. For Sci 22:329-330

Johnsson H (1940) Cytological studies of diploid and triploid Populus tremula and of crosses between them. Hereditas 26:321-352

Johnsson H, Eklundh C (1940) Colchicine treatment as a method in breeding hardwood species. Sven Papp Tidn 43:373-377

Kang XY, Zhu ZT (1997) A study on the $2 n$ pollen vitality and germinant characteristics of white poplars. Acta Botanica Yunnanica 19:402-406

Kang XY, Zhu ZT, Zhang ZY (1999) Morphology and meiosis of allotriploid Chinese white poplar. J Beijing For Univ 21:1-5 
Kang XY, Zhu ZT, Zhang ZY (2000a) Suitable period of high temperature treatment for $2 \mathrm{n}$ pollen of Populus tomentosa $\times P$. bolleana. J Beijing For Univ 22:1-4

Kang XY, Zhu ZT, Zhang ZY (2000b) Breeding of triploids by the reciprocal crossing of Populus alba $\times P$. glandulosa and $P$. tomentosa $\times P$. bolleana. J Beijing For Univ 22:8-11

Li YH, Kang XY, Wang SD, Zhang ZH, Chen HW (2008) Triploid induction in Populus alba $\times$ P. glandulosa by chromosome doubling of female gametes. Silvae Genet 57:37-40

Mashkina OS, Burdaeva LM, Belozerova MM, Vyunova LN (1989) Method of obtaining diploid pollen of woody species. Lesoved $1: 19-25$

Mendiburu AO, Peloquin SJ (1977) The significance of 2n gametes in potato breeding. Theor Appl Genet 49:53-61

Müntzing A (1936) The chromosomes of a grant Populus tremula. Hereditas 21:383-393

Nilsson-Ehle H (1936) Note regarding the gigas form of Populus tremula found in nature. Hereditas 21:372-382

Nomura K, Nakajima J, Ohta H, Kagawa H, Tanaka H, Unuma T, Yamauchi K, Arai K (2004) Induction of triploidy by heat shock in the Japanese eel Anguilla japonica. Fish Sci 70:247-255

Randolph LF (1932) Some effects of high temperature on polyploidy and other variations in maize. PNAS 18:222-229

Seitz FW (1954) The occurrence of triploids after self-pollination of anomalous androgynous flowers of a grey poplar. Z Forstgenet $3: 1-6$

van Buijtenen JP, Joranson PN, Einspahr DW (1958) Diploid versus triploid aspen as pulpwood sources with reference to growth, chemical, physical and pulping differences. Tappi 41:170-175
Veilleux RE (1985) Diploid and polyploid gametes in crop plants: mechanisms of formation and utilization in plant breeding. Plant Breed Rev 3:253-288

Wahid A, Gelani S, Ashraf M, Foolad MR (2007) Heat tolerance in plants: an overview. Environ Exp Bot 61:199-223

Wang J, Kang X, Zhu Q (2010a) Variation in pollen formation and its cytological mechanism in an allotriploid white poplar. Tree Genetics \& Genomes 6:281-290

Wang J, Kang X, Li D, Chen H, Zhang P (2010b) Induction of diploid eggs with colchicine during embryo sac development in Populus. Silvae Genet 59:40-48

Weisgerber H, Rau HM, Gartner EJ, Baumeister G, Kohnert H, Karner L (1980) 25 years of forest tree breeding in Hessen. Allg For 26:665-712

Winton L, Einspahr DW (1970) Tetraploid aspen production using unreduced triploid pollen. For Sci 16:180-182

Yang H, Guo X (2006) Polyploid induction by heat shock-induced meiosis and mitosis inhibition in the dwarf surfclam, Mulinia lateralis Say. Aquaculture 252:171-182

Zhang XZ, Liu GJ, Yan LY, Zhao YB, Chang RF, Wu LP (2002) Creating triploid germplasm via induced $2 \mathrm{n}$ pollen in Capsicum L. J Horticult Sci Biotechnol 78:84-88

Zhang S, Qi L, Chen C, Li X, Song W, Chen R, Han S (2004) A report of triploid Populus of the section Aigeiros. Silvae Genet 53:69-75

Zhang SG, Chen CB, Han SY, Li XL, Ren JZ, Zhou YQ, Song WQ, Chen RY, Qi LW (2005) Chromosome numbers of some Populus taxa from China. Acta Phytotaxon Sin 43:539-544

Zhu ZT, Lin HB, Kang XY (1995) Studies on allotriploid breeding of Populus tomentosa B301 clones. Sci Silvae Sin 31:499-505 